\title{
USING GEOLOGICAL DATA TO IDENTIFY SOME ENVIRONMENTAL PROBLEMS ASSOCIATED WITH EXISTING PIPELINES AND OTHER LINEAR STRUCTURES
}

\author{
M G Culshaw, ${ }^{1,2}$ S J Booth, ${ }^{1}$ A D Gibson ${ }^{3} \&$ R Dearden ${ }^{1}$ \\ 1 British Geological Survey \\ 2 University of Birmingham, UK \\ 3 University of Portsmouth, UK, formerly British Geological Survey
}

\begin{abstract}
Pipelines and other linear structures often cover large distances across topographically and geologically varied ground. In the last decade, or so, geological information has started to become available in digital form for countries and regions. This enables a wide-range of users, including pipeline operators, to access interpreted geohazard information not only for the construction of new linear infrastructure, but also to assess a range of geological risks to existing linear infrastructure that might have been constructed before such information was available.
\end{abstract}

Examples of the use of such information are discussed in relation to Great Britain's national natural gas and ethylene pipeline networks and the possible raising of the Thames Estuary flood embankment that helps to protect London from flooding. Future developments in the provision of geological information are discussed, including bespoke information systems in which the outputs are defined by the users rather than the information holders.

\section{INTRODUCTION}

One of the main roles of a Geological Survey is the collection, validation and management of geological data that are in the public domain, that is, data acquired by survey and research using public money, data provided by other public bodies and data obtained from private owners. However, there is also a responsibility to make the data accessible to potential users, unless the owner (outside the public sector) has required that the data are to be held confidentially. Even in this case, there is usually a limit on the term of confidentiality. However, 'raw' data may be of limited use to many potential users so Geological Surveys provide interpreted outputs, the most traditional and well known of which is the lithostratigraphical map. Until about two decades ago, almost all geological maps (whether stratigraphical or of other types) were analogue and printed on paper. With the rapid development of GIS (Geographical Information Systems) technology and the increasing digitisation of geological data, geological survey map outputs are frequently produced in digital format so that users are no longer required to buy rectangular-shaped pieces of paper but can specify the area for which they require information. Indeed, many 'traditional' geological maps do not exist primarily in paper form but have to be printed 'on demand (Culshaw et al. 2006).

As the coverage of high quality, two dimensional, lithostratigraphical maps approaches completion at medium scale (1:25 000 to 1:100 000), it becomes possible to use this data set, with others, to derive a series of interpreted national maps of a range of types and for multiple purposes. One example of this type of output is the national geohazard susceptibility map. In Britain, a suite of digital maps of this type has been developed using the basic lithostratigraphical map as the starting point. Other data inputs (if available) might include a digital elevation model (to determine slope steepness), hydrogeological information (for groundwater conditions such as the position of the water table and the location of springs), geotechnical information on the properties of geological formations and information on known occurrences of geohazards such as 
landslides and sinkholes. Such a geohazard susceptibility system at the national level (called GeoSure) has been developed for the whole of Britain (Harrison \& Forster 2009, Walsby 2007, 2008). Digital national geohazard susceptibility maps exist for swellshrink, landslides, dissolution, compressibility, collapsibility, running sand, abandoned mineworkings (excluding coal) and radon. Figures 1a \& b show the national maps for landslides and dissolution. This system has been used extensively by different user groups, for example, surveyors, estate agents and potential purchasers, in relation to house purchase and insurers to estimate the possible financial risks to properties from geohazards (Culshaw \& Harrison 2010).

Some Geological Surveys or equivalent national organisations, have built databases of geohazard occurrences and of geotechnical properties. In Britain, such databases exist, though they are far from complete (Cooper et al. 2001, Farrant \& Cooper 2008, Self et al. 2012, Foster et al. 2012). The landslide database contains information on close to 16 000 landslides and the karst database on around 52000 features related to dissolution. The geotechnical properties database has data on nearly 500000 engineering soil and rock samples obtained from just under 100000 boreholes and other excavations. Figures $2 a, b$ \& c show the distribution of landslides, karst features and samples for which there is geotechnical data, respectively, as of July 2012. The datasets developed so far are qualitative hazard maps, not risk maps. Creating true risk maps is a very difficult and time-consuming process.

Such information sets are also useful to other users. One of these user groups includes the owners and operators of linear structures such as pipelines, flood defence systems, railways and roads. This paper describes two case studies. The first outlines how the geohazard information, briefly described above, has been used by national pipeline operators to assess the health and safety risk of pipeline rupture by landslides and dissolutions features. The second illustrates how a major flood defence network along the River Thames was assessed to determine places where excessive or differential subsidence might pose a risk to the integrity of the flood embankments.

\section{CASE STUDY 1 - THE NATIONAL GAS AND ETHYLENE PIPELINE NETWORKS}

As in many countries, Great Britain (GB) (which is made up of England, Scotland and Wales) has a large network of pipelines, carrying a range of liquids and gases, such as water, natural gas and petroleum products. While these pipelines were constructed following site investigations, at the time, information on a range of geohazards had not been compiled into accessible national databases. The drive to do this followed a period of relatively severe drought in the south east and Midlands of England in 1989-90. This drought resulted in a series of insurance claims for 'subsidence' damage to houses which cost the British insurance industry around $£ 1 \mathrm{bn}$. To enable the industry to understand risks better, research was carried out by the British Geological Survey (BGS) that resulted in the production of a series of geohazard susceptibility maps for most of GB (Culshaw 1993, Culshaw \& Kelk 1994, Rosenbaum \& Culshaw 2003, Culshaw \& Harrison 2010). However, there were deficiencies in the geohazard susceptibility maps caused, particularly, by the limited availability in digital form of the geological and other data used to produce the maps. In the early 2000 s, this resulted in the development, by the BGS, of a new digital geohazard susceptibility system (Harrison \& Forster 2009, Walsby 2007, 2008).

In the early part of the $21^{\text {st }}$ Century, there was an increasing requirement on the owners and operators of pipelines carrying hazardous fluids (Major Accident Hazard Pipelines MAHPs) to demonstrate the level of risk of rupture from a range of external hazards, including geohazards. This requirement resulted in the operators of the GB natural gas and ethylene pipeline networks seeking to identify those places where their pipeline 
networks might be at risk of rupture from the occurrence of a geohazard. The two networks were different in size, the natural gas network involving around $18000 \mathrm{~km}$ of pipeline, while the ethylene network had about $1000 \mathrm{~km}$ of pipeline (Figures 1a and b).

Of the natural geohazards for which ground movement susceptibility has been assessed (shrinkage and swelling of clay, mass movement, natural dissolution, compressible soils, running sands, collapsible soils), mass movement and natural dissolution were the two that had the greatest potential to cause pipeline rupture. Consequently, the assessments were carried out for these two geohazards.

Landsliding includes movement of material by falling, toppling, sliding and flowing depending on the topography of the ground surface and the nature of the material of which it is composed. The impact that such movements have on rigid linear infrastructure, such as a pipeline, will vary but typical results include sudden impact, loading, longitudinal compression or tension and lateral deflection or shearing.

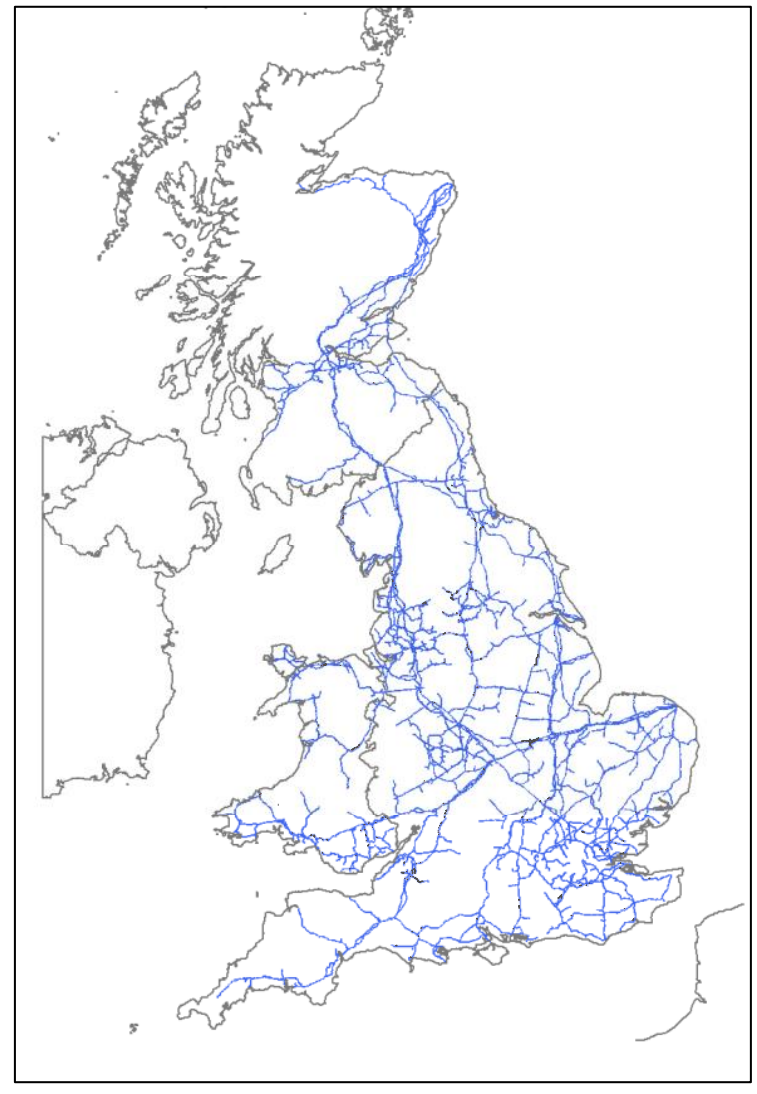

Figure 1a. Natural gas pipeline network for Great Britain

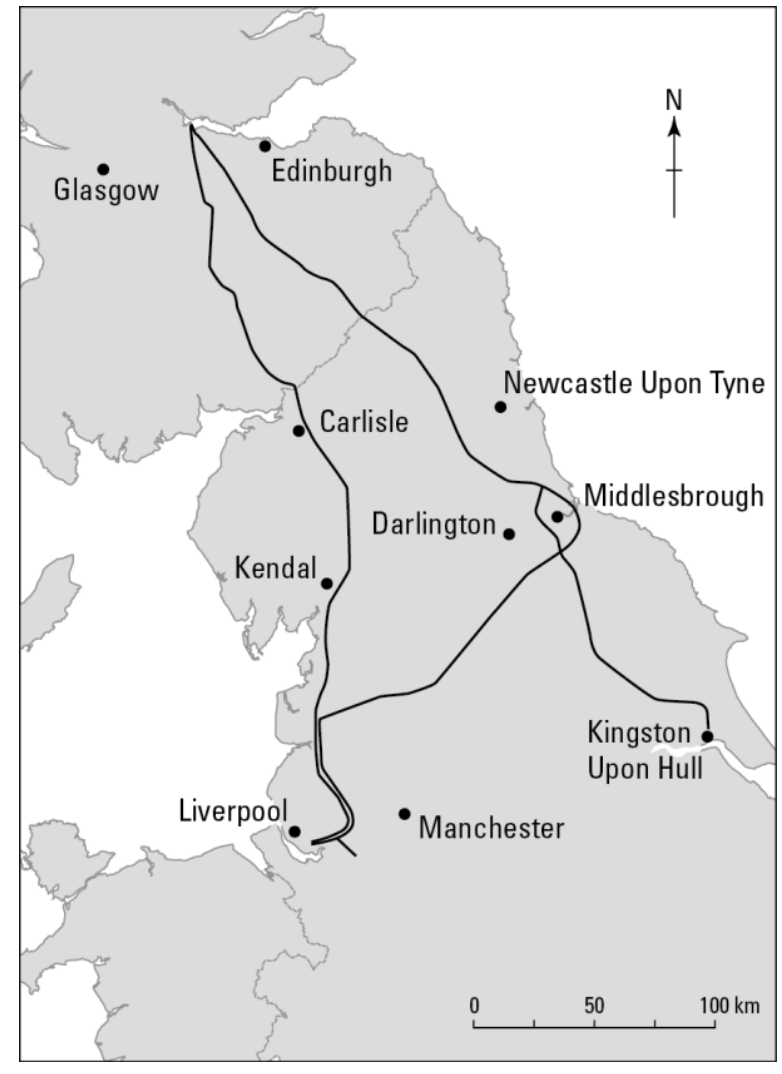

Figure 1b. Ethylene pipeline network for Great Britain

The dissolution of soluble rocks in Great Britain is much less widespread than that of landsliding. Britain has four types of soluble (or karstic) rocks: mainly Carboniferous limestone, Cretaceous chalk (the most widespread carbonate rock in Britain), Permian gypsum and mainly Permo-Triassic salt, each with a different character and associated problems (Cooper et al. 2001). Subsidence, often triggered by water or brine abstraction, occurs widely where soluble rocks occur, especially where soluble rocks are overlain by a thin superficial veneer. At the surface, the presence of sinkholes provides evidence of this. 
Dissolution of soluble rocks can cause significant engineering and foundation problems that may affect pipelines. The nature and scale of dissolution varies according to the rock type and the nature of the site. The nature of dissolution means that the hazards posed to linear route infrastructure such as pipelines are dominated by subsidence and ground collapse (sinkholes) (Waltham et al. 2005). Large-scale collapses in Great Britain are rare, but can involve voids greater than $30 \mathrm{~m}$ in diameter. Such failures would result in a sudden and complete loss of support to the pipeline. Smaller collapses are far more frequent and are unlikely to cause significant hazard to the pipeline itself but may still affect supporting infrastructure. Lateral movement of the ground surface can also be caused by dissolution. This tends to occur where solution leads to undermining of a thick cover of superficial materials.

\section{Geohazard Assessment System}

A system that could provide information on geohazards for the two pipeline networks was developed. The system had to fulfil two functions:

- to provide a consistent, national assessment of geohazards affecting the pipeline networks;

- to provide information regarding the spatial distribution and the severity of geohazards.

Digital files of each pipeline network were provided by the operators. A buffer around the each network was created. For operational reasons this was set to a width of $500 \mathrm{~m}$ (250m either side of the centre-line) for the natural gas pipeline network; for the ethylene pipeline network two buffer zones were set at $140 \mathrm{~m}$ and $400 \mathrm{~m}$ wide $(70 \mathrm{~m}$ and $200 \mathrm{~m}$ either side of the centre-line). These buffered networks were then clipped against the geohazard susceptibility dataset to produce a GIS layer indicating the areas of high hazard rating for the pipeline.

Data from the geohazard susceptibility dataset were modified by reference to data in the BGS National Landslide Database and BGS National Karst Database. This showed areas where additional data regarding landslide occurrence have been collected since the original geohazard susceptibility dataset was interpreted. Delineated areas were incorporated into the GIS and each given a hazard rating on a scale of zero to five for landslide hazard and one to five for dissolution hazard (Table 1). The results were output as GIS layers of landslide hazard and dissolution hazard. Figures $2 \mathrm{a}$ and $\mathrm{b}$ show parts of the gas pipeline network that are subject to significant (moderate to high and high, Table 1) landslide and dissolution hazard.

For each of the pipeline networks, the percentage of the length of each network falling in classes 4 and 5 for the two geohazards are shown in Table 2.

Table 2. Percentage of each pipeline network falling in geohazard class 4 and 5 combined and for which there was no geohazard susceptibility for the various buffer zones

\begin{tabular}{|c|c|c|c|}
\hline & $\begin{array}{l}\text { Percentage of } \\
\text { natural gas } \\
\text { pipeline network. } \\
500 \text { m total width } \\
\text { buffer zone }\end{array}$ & $\begin{array}{l}\text { Percentage of } \\
\text { ethylene pipeline } \\
\text { network. } 140 \mathrm{~m} \\
\text { total width buffer } \\
\text { zone }\end{array}$ & $\begin{array}{l}\text { Percentage of } \\
\text { ethylene pipeline } \\
\text { network. } 400 \mathrm{~m} \\
\text { total width buffer } \\
\text { zone }\end{array}$ \\
\hline $\begin{array}{l}\text { Landslide classes } \\
4 \text { and } 5 \text {, combined }\end{array}$ & 0.9 & 2.2 & 2.5 \\
\hline No landslide & 50.1 & 0.2 & 0.3 \\
\hline
\end{tabular}




\begin{tabular}{|l|c|c|c|}
\hline susceptibility & & \\
\hline $\begin{array}{l}\text { Dissolution } \\
\text { classes 4 and 5, } \\
\text { combined }\end{array}$ & 0.9 & 2.3 & 2.4 \\
\hline $\begin{array}{l}\text { No dissolution } \\
\text { susceptibility }\end{array}$ & 84.2 & 91.1 & 91.1 \\
\hline
\end{tabular}
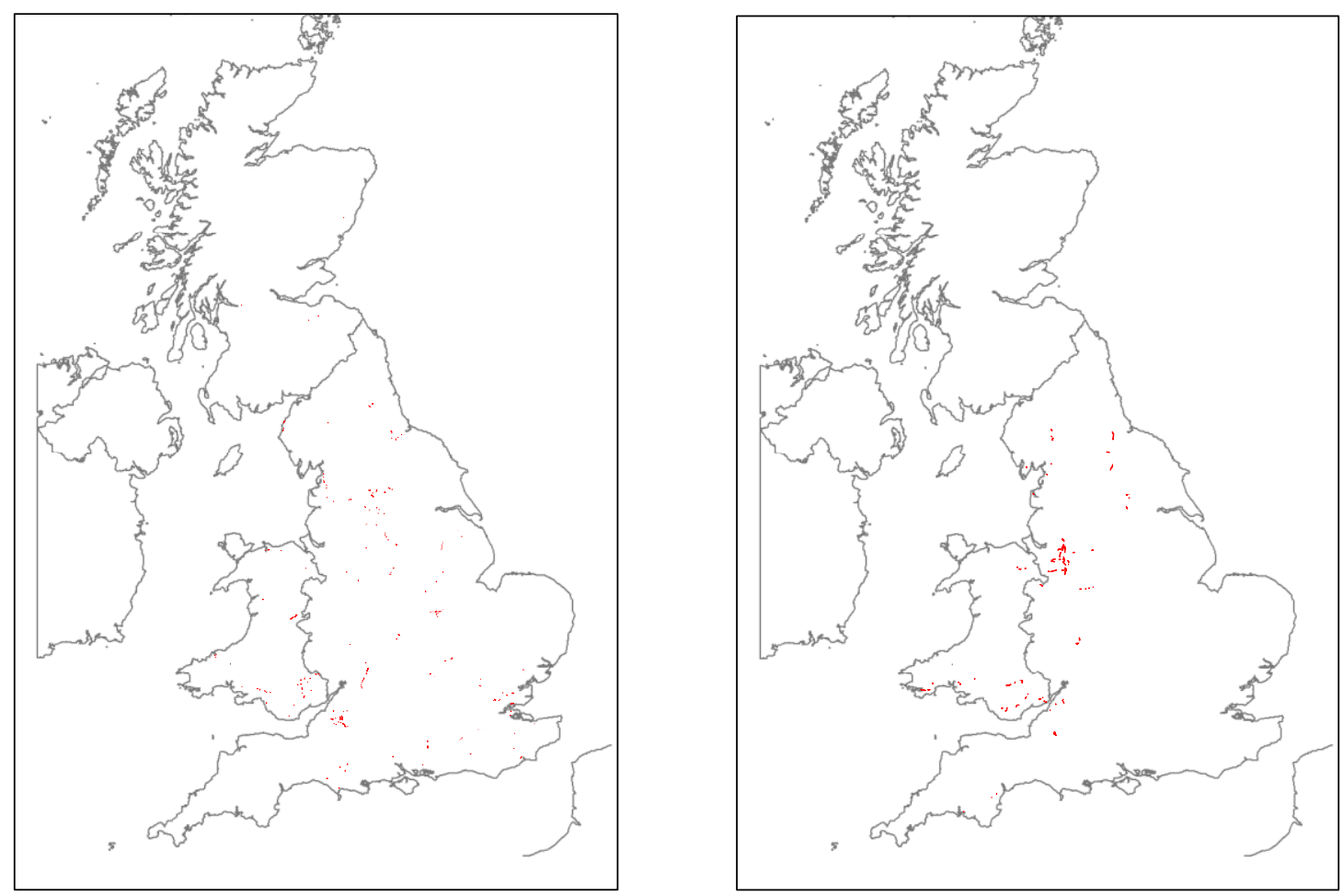

Figure 2. Parts of the gas pipeline network subject to moderate to high and high a) landslide hazard and b) dissolution hazard.

\section{CASE STUDY 2 - THE RIVER THAMES FLOOD DEFENCE SCHEME}

There are global and national concerns about the vulnerability of population, buildings and infrastructure on low-lying ground given the now accepted threat of rising sea levels, whether associated with global warming-driven climate change, increased storminess, or brought about by changes in coastal configuration. In addition, since the Last Glacial Maximum (LGM) (c.20 000 years BP), mainland Britain relieved of the weight of thicknesses of ice (in excess of $1000 \mathrm{~m}$ in the western Highlands of Scotland) has responded by the ice loaded areas rising (a 'springboard' affect) and the whole of Britain being subjected to a c. $120 \mathrm{~m}$ sea-level rise from the maximum of the LGM glaciation to about 6,500 years ago. Over the past 6500 years land uplift has been greater than sea-level rise in the areas of substantial ice load but, elsewhere, sea-level has oscillated around the present level with slight subsidence occurring due to the deglacial melt-water load on the Atlantic basin and the continental shelf, the effect of farfield ice sheets and local factors such as onshore and offshore geomorphology and sediment compaction. Typical rates of subsidence in eastern and southern Britain over this period are between 0.5 and $1 \mathrm{~mm} /$ year (Gehrels 2010).

As with many global megacities, a good part of London's essential infrastructure, property (500 000 residential and 40000 non-residential properties valued at more than $£ 80$ billion), key government and financial institutions are located on the alluvial 
floodplain of the River Thames and its lower river terraces. In addition, London is the home to around 8.2 million people (March 2011 census), 1.25 million of whom are vulnerable to flooding of the River Thames and the Thames Estuary. These figures are set to increase substantially as the capital expands, this expansion extending particularly along the hinterland corridor of the outer Thames estuary in the neighbouring counties of Kent and Essex.

The Environment Agency (EA) (a national government agency) in Britain has, as one of its responsibilities, the management of tidal flood risk through London and the Thames estuary. The Thames Estuary 2100 (TE2100) project was established by the Environment Agency in 2002 with the aim of developing a strategic flood risk management plan for London and the Thames estuary through to the end of the $21^{\text {st }}$ century. The plan primarily looked at tidal flooding, though other sources of flooding, including high river flows as a result of heavy rainfall and surface water flooding, were considered. The key driver for the project was to consider how tidal flood risk was likely to change in response to future changes in climate and people and property in the floodplain. The plan covers the tidal Thames and its floodplain from Teddington, in the west, to Sheerness/Shoeburyness in the east. It is integrated with adjoining catchment flood management plans (CFMPs), which cover non-tidal flood risk management, with the shoreline management plans (SMPs) in Kent and Essex, which cover coastal flood and erosion risk management.

The TE2100 Plan (Anon. 2012) recognised that the $300 \mathrm{~km}$ of existing Thames flood defence structures provided by embankments ('soft' defences), walls, barriers and gates (collectively 'hard' defences) were gradually deteriorating and would reach the peak of their design lives during the next 20-30 years (much of the defence emplacements were designed to protect against a 1 in 1000 year flood up to 2030 (Anon. 2009). In addition, less developed areas included installations constructed to lower standards and ridge heights. Within the City and adjacent populated and commercial area these structures tend to be made of concrete and steel; elsewhere, soil levees are the norm. Critically, all these structures are founded on potentially compressible Holocene sediments.

Integral to the TE2100 Strategic Environmental Assessment was a baseline audit. The British Geological Survey (BGS) with other scientific agencies has been involved in aspects of this audit including an assessment of relative land and sea level changes in London and the Thames Estuary and of the near-surface geology underlying the estuary and its hinterland.

Global Positioning System (GPS) data from the Institute of Engineering Surveying \& Space Geodesy at the University of Nottingham, Absolute Gravimetric data from the Proudman Oceangraphic Laboratory and analysis of Persistent Scatterer Interferometric Synthetic Aperture Radar (PSInSAR) data by Nigel Press Associates has enabled collaborating teams (including BGS) to gain a broad picture of land deformation (in millimetres per year) across the Thames region as a whole.

After numbers of local factors affecting ground elevation such as loading by tidal movements, subsidence due to natural ground compression, diurnal temperature and atmospheric changes, the study (Anon. 2007) concluded that relative sea level rise equates to a year-on-year 2-3 mm increase. Using these data the BGS produced a Thames region map that showed domains of movement. Close to the estuary, this relative subsidence is in the range -1.5 to $-2.5 \mathrm{~mm}$ per year whilst adjacent but widespread areas record relative subsidence movements of between -0.75 to $-1.5 \mathrm{~mm}$ per year. 
Whereas the EA engineers had a good understanding of their flood protection installations in terms of construction, it was generally recognised that the subsurface underlying these structures was far less well understood. In particular, there were concerns about the potential loading implications should remediation/refurbishing priorities dictate that sections of flood embankments needed significant height increases to accommodate anticipated water level rises. Allied to this concern was the knowledge that many kilometres of soil embankments ('soft' defences) were constructed with material sourced from linear 'borrow' trenches immediately adjacent to the 'dry' side of the embankment. What this soil material comprised was not always known except in those sections where repairs had been recently undertaken. It was appreciated that embankments of clay-rich material are susceptible to swelling and shrinking. Over time, cracks and fissures resulting from this natural process potentially leads to the loss of structural integrity of the embankment.

Sourcing and getting-to-site additional construction material is also another significant consideration - could material be taken from existing adjacent trenches without compromising the integrity of the existing embankment and, importantly, the planned for increased height embankment? Could the ground beneath the new, raised structure sustain the increased loading? What was the likelihood and extent of differential settlement? Key to addressing these questions was an improved understanding of the Holocene sequence beneath the installations - a sequence known to variably comprise up to three layers of compressible peat, interbedded with saturated, estuarine muds.

The terms of reference for the BGS's investigation were to:

- review geological and geotechnical data held in the BGS archives

- produce a geological and geotechnical appraisal of the ground beneath the flood defence structures

- include a summary geotechnical literature review

- make recommendations about possible further work based on an evaluation of the quality and distribution of the information reviewed.

The main output of the completed work comprised eleven GIS layers of geological and geotechnical data for a $500 \mathrm{~m}$ wide buffer zone along $235 \mathrm{~km}$ of flood defence structures (Table 3). Key base level information, along with geotechnical interpretations based on an analysis of the data, is presented in the form of cross sections of 47 long sections of the flood defences, each $5 \mathrm{~km}$ in length (Figure 3). This information provided a background for the assessment of potential ground instability beneath existing River Thames' flood defence structures and indicated those areas where more detailed site specific assessments were needed should modifications of the defence structures be planned.

Table 3. Attributed GIS layers of information

\begin{tabular}{|l|l|}
\hline Layer Name & Description \\
\hline Buffer $250 \mathrm{~m}$ & $\begin{array}{l}\text { A 250m wide buffer either side of the defence line. This } \\
\text { is the spatial basis for this project and provides a 500m } \\
\text { corridor within which geological and geotechnical } \\
\text { information held was presented. }\end{array}$ \\
\hline $\begin{array}{l}\text { Current flood defences } \\
\text { (hard and soft structures) }\end{array}$ & $\begin{array}{l}\text { Current position of flood defences in the Thames } \\
\text { Estuary (Environment Agency). }\end{array}$ \\
\hline Geology_bedrock & $1: 50000$ scale solid geology within the 500m corridor. \\
\hline Geology_superficial & $\begin{array}{l}1: 50000 \text { scale superficial geology within the 500m } \\
\text { corridor. }\end{array}$ \\
\hline Geology_artificial & $1: 50000$ scale artificial geology (e.g. made ground, \\
\hline
\end{tabular}




\begin{tabular}{|l|l|}
\hline Layer Name & Description \\
\hline Boreholes & worked ground etc.) within the 500m corridor. \\
\hline Selected_Boreholes & $\begin{array}{l}\text { Location of borehole records (7307 records) held by } \\
\text { BGS that fall within the 500m corridor. }\end{array}$ \\
\hline Geotech_Info_BHs & $\begin{array}{l}\text { Boreholes records used for correlating geological cross- } \\
\text { sections (520 records). }\end{array}$ \\
\hline Engineering_Desc_BHs & $\begin{array}{l}\text { Borehole records for which geotechnical data exists } \\
\text { within the BGS Geotechnical Database. }\end{array}$ \\
\hline SI_Reports & $\begin{array}{l}\text { Boreholes for which engineering descriptions exist } \\
\text { within the BGS Geotechnical Database. }\end{array}$ \\
\hline Cross_Sections & $\begin{array}{l}\text { Relevant site investigation reports held in the BGS } \\
\text { Geotechnical Database. }\end{array}$ \\
\hline & $\begin{array}{l}\text { A line layer based on the flood defence line divided up } \\
\text { into 47 approximately 5 km long sections; 27 on the } \\
\text { north bank (N1 to N27) and 20 on the southern bank } \\
\text { (S1 to S20). Within the GIS environment, each section } \\
\text { is hyper-linked to a relevant geological cross-section. }\end{array}$ \\
\hline
\end{tabular}

In-house modelling software (GSi3D) was used to construct the cross-sections (Ford et al. 2010).

\section{DISCUSSION}

\section{Targeting the user-group}

The common challenge experienced in providing

geological/geohazard/geoenvironmental audits is effective communication to the usergroup audience. Generally, this audience falls into four categories:

1. High level planning and management who need information for investment decisions.

2. Project Manager(s) who need detail for various design and construction phases of the project.

3. Third party consultees generally concerned with the environmental impact of the route proposals.

4. The main works contractor involved in construction. The geohazard/environmental appraisals often form part of the 'Invitation to Tender' (ITT) documentation. As such, they will indicate known 'difficult ground' and minimise/avoid occurrences of 'unforeseen ground conditions', which may have significant cost implications.

Thus, the primary concerns and the level of technical understanding of the various components of the audience are wide-ranging. It is essential that the presentation of factual data and interpretation(s) are clearly structured within the reports to facilitate use and comprehension by this audience.

\section{Route types}

Linear routes are either:

- Pre-existing routes where a geological/geohazard/geoenvironmental audit is required as a legal requirement or to determine the likelihood of a problem should operating conditions change (strengthening of flood defence embankments) or to address a known problem where the cause and remedy is not clear (for example, soil embankment composition).

- Future routes where the overall viability of the route is considered initially in a relatively large search area and, subsequently, within potential route corridors to 
determine the geological/geohazard impacts on each of the identified route corridor options and, thereby, produce a sequential order of preference.

Geohazard implications for routing

The general requirements of a geological/geohazard/geoenvironmental audit include:

- assessment of the impacts of the geology, hydrology, hydrogeology - the ground conditions - on the route selection and the construction and operation of the proposed linear structure;

- assessment of the effect of the proposed linear structure on the local geology, hydrology and ground conditions (in other words, how they might be changed by the structure);

- identification of conditions that pose significant constraints upon, or risks to, the successful, timely and cost effective completion of the project and, subsequently, the safe operation and maintenance of the proposed linear structure;

- recommendation of any mitigation measures (including the geographical extent of such mitigation measures) should they be needed along the route.

\section{Presentation of the geological/geohazard/geoenvironmental audit results}

The authors' experience of providing geological/geohazard/geoenvironmental audits has shown that some of the users can be overwhelmed by the amount of information and the technical terminology presented in these reports. Clearly, it is important that the audits are not just part of standard data gathering exercise - the information should be tailored for the engineer or planner for whom it was intended and the geotechnical or environmental implications presented simply and clearly.

Notwithstanding the rapid advances in computing technology and the flexibility of data manipulation provided by GIS systems, providing information that the audience can usefully assimilate remains a challenge. One approach is to illustrate the information schematically (Figure 4). In this way the user, whatever their interest in the proposed scheme, is able to readily access data relevant to their needs. Ideally, this schematic 'high level' index should be hyper-linked to increasingly detailed information on each topic including a glossary of technical terms perhaps not familiar to the user.

The cost-benefits of such an approach are obvious; in particular, the scheme can be configured to address a crucial element of the management decision-making chain, namely, that of the financial managers (highlighted in Figure 4). If difficult technical considerations are anticipated the scheme enables these issues to be 'flagged up' during the early phases; thus, these difficulties can be considered in terms of their impact on logistics, duration of the construction and, of course, the overall budget.

\section{Developments in the provision of digital data}

The main holders of spatial geological data in most countries are geological surveys and their equivalents. The last two decades have seen the rapid digitisation of these holdings in many geological surveys. However, these data, which consist of a range of specific datasets, are not necessarily directly useful to the specific needs of individuals and organisations. In recent years, there has been increased efforts to develop 'products' based on the geological and other datasets that address the specific requirements of users. In particular, these 'products' might include suitability maps to provide a 'screening level' indication of the suitability of the subsurface for a particular purpose. Examples include digital spatial data tools showing the suitability of the ground for the use of ground source heat pumps, for contaminated site evaluation and prioritisation and for the use of sustainable drainage systems (SuDS) (Dearden \& Price 2011, 2012, Dearden et al. 2013). 

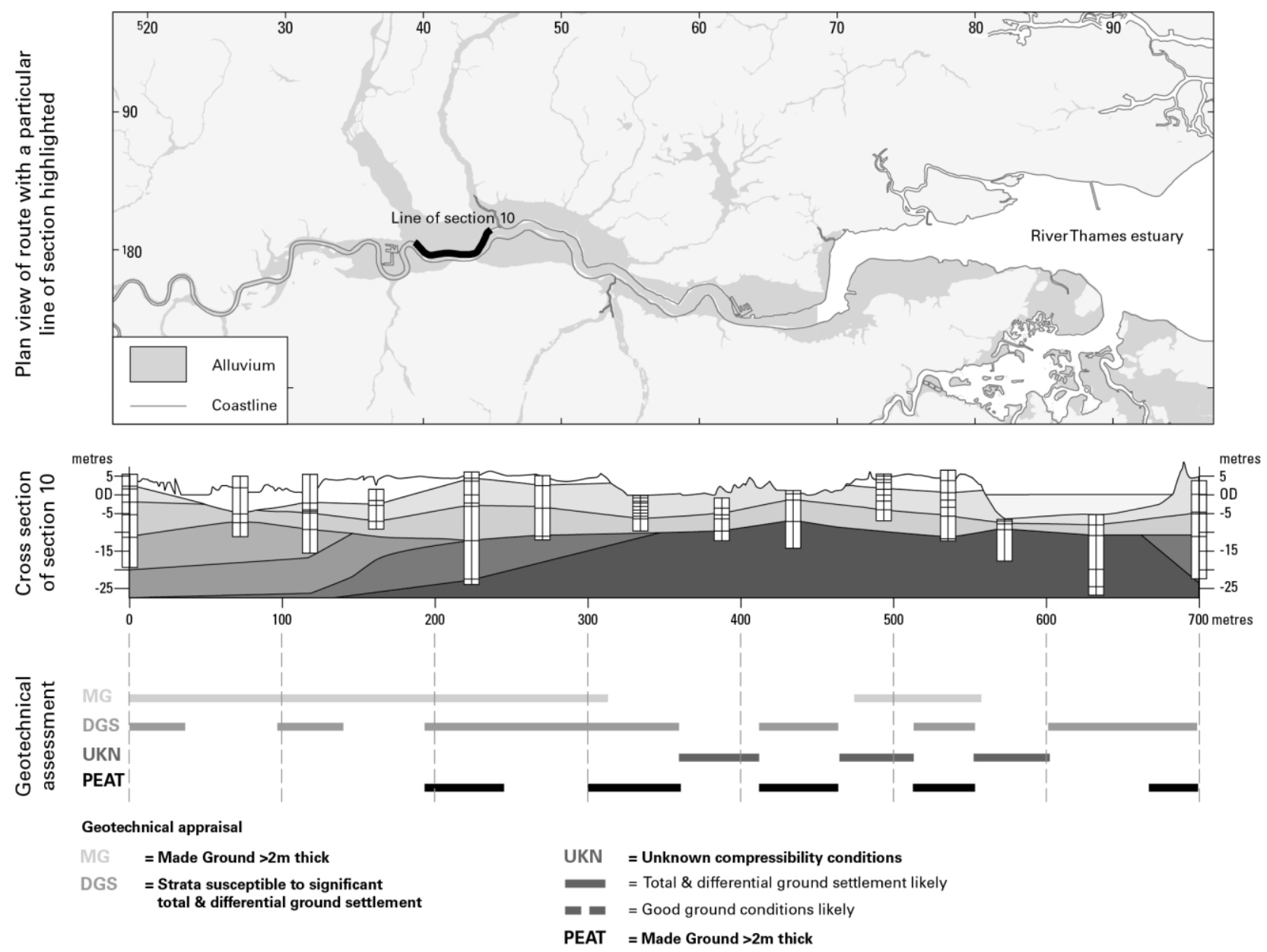

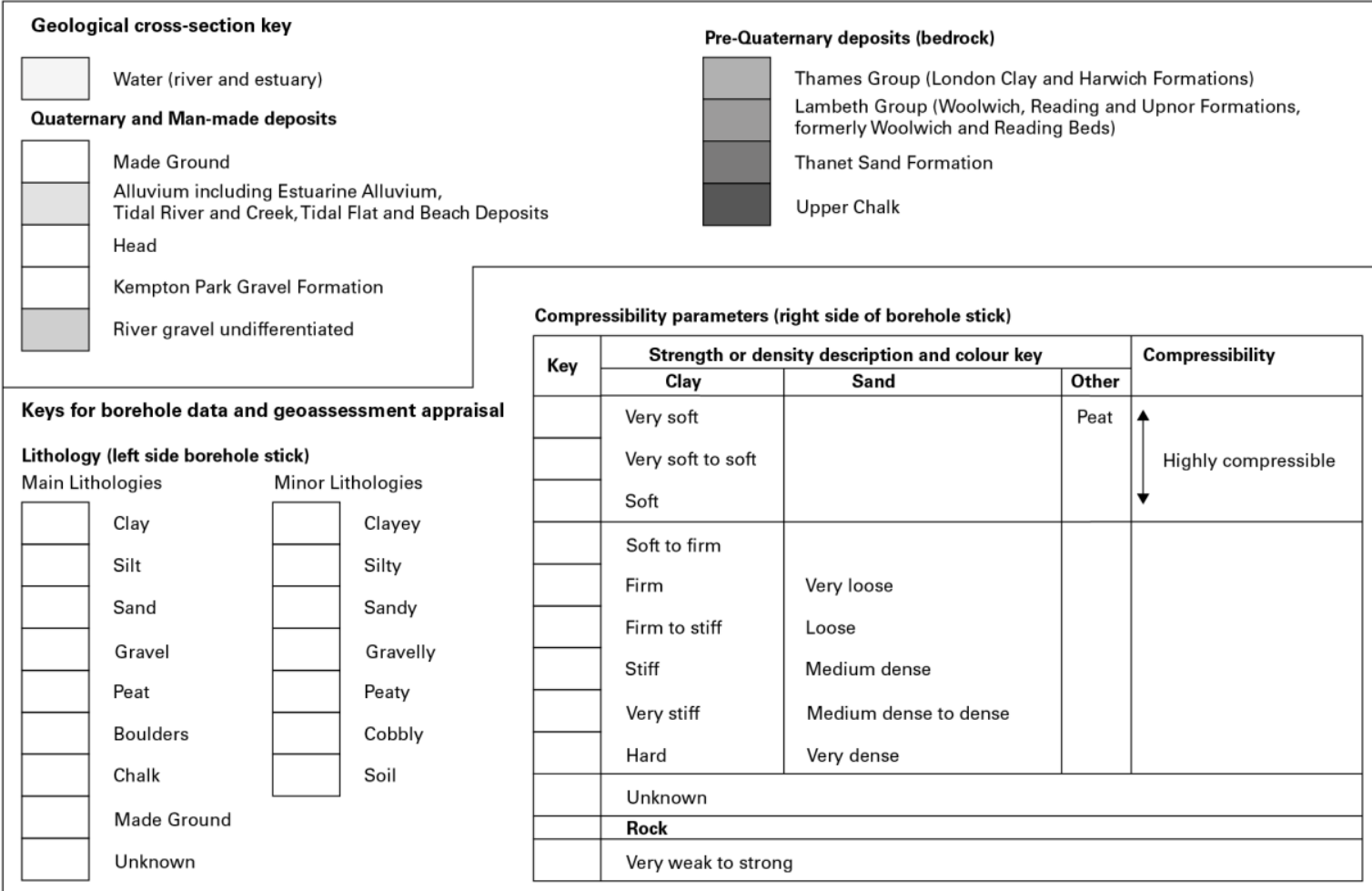

Figure 3. Example of a GIS hyper-linked cross section 


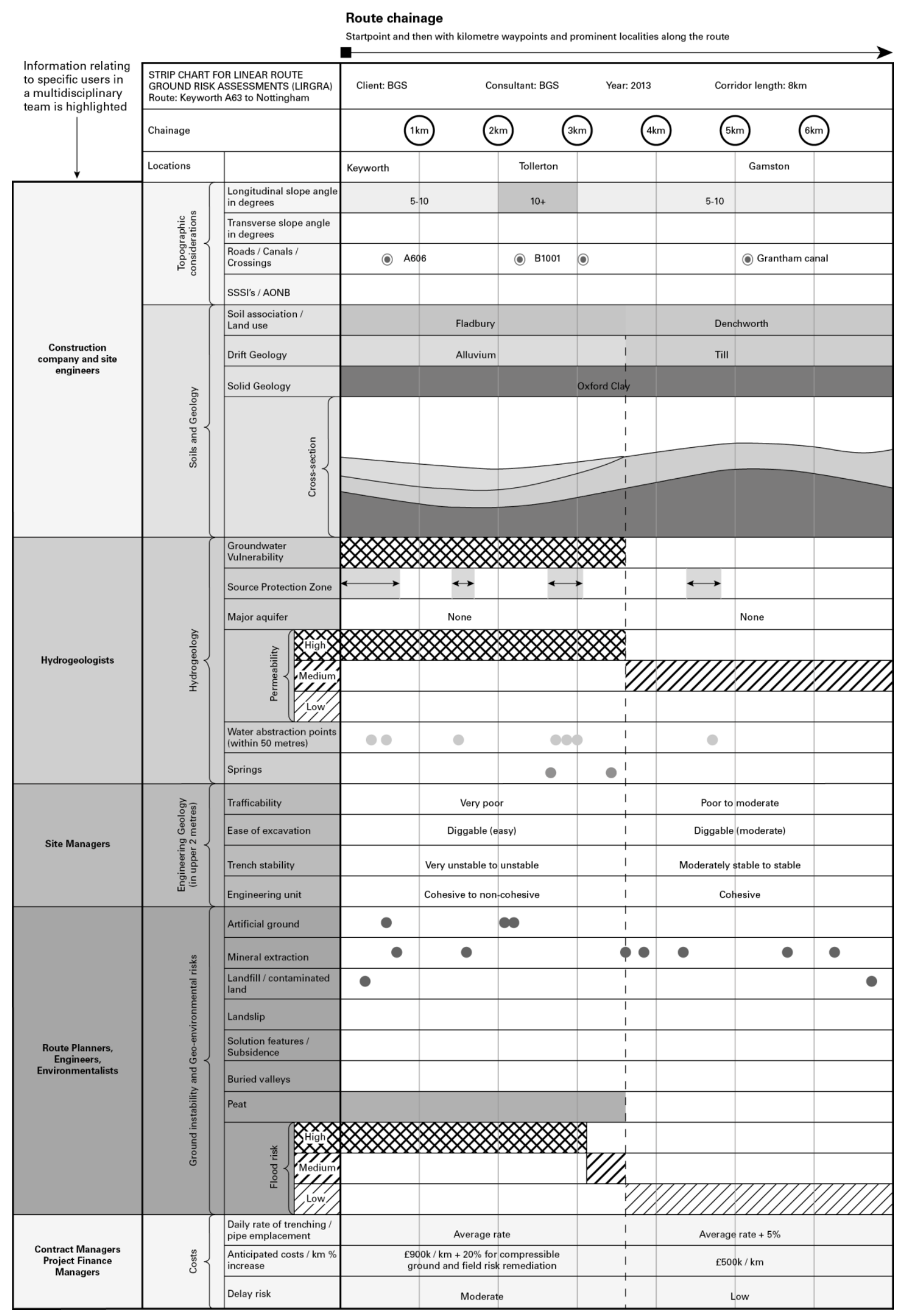

Figure 4. Schematic diagram presenting comprehensive meta-data route information; specific data and interpretations that can be accessed by a range of users by means of hyper-links. 
Most of the datasets that are available at the BGS are derived wholly, or in part, from the BGS's 1: 50000 scale Digital Geological Map, DiGMapGB 50 (BGS, 2010). Over the past 10 years, re-attribution of the geological map polygons with a range of property data has resulted in a number of directly derived datasets (including permeability, geological indicators of flooding, swelling clays, collapsible ground, compressible ground, running sands and aquifer predominant flow mechanism) and more complex derived datasets (including landslides, soluble rocks and susceptibility to groundwater flooding). The latter were developed using algorithms to combine data from the digital geological map and other data sources, including for example, digital terrain models and borehole data (Walsby 2007).

However, it does not follow that an organisation such as the BGS, which has spent much of its almost 180 year existence acquiring, validating and managing geological data, is, necessarily, best placed to decide what types of derived and interpreted datasets users might need and want. Consequently, systems are now being developed to help users create, on-line from the existing data and information holdings, outputs that more exactly meet their needs. The BGS has developed a means of doing this that is called the 'Online Suitability Map Generator' (OSMG); this provides an assessment of ground conditions for any application (within reason), by generating bespoke summary maps and component maps. One such application could be information for pipeline planning or maintenance. The OSMG has three parts:

- data searching to find the dataset(s) the user needs; the objective is to create a web-based facility that connects the user's purpose or question (for example, 'I need to build a pipeline from location a to location b; what natural and artificial geohazards are known along the route?), with the datasets that will help provide a screening-level solution;

- user-defined assignment of suitability scores to the hazard ratings of each geohazard dataset indicating the users' assessment of suitability/susceptibility;

- generation of bespoke suitability maps.

Systems such as the OSMG require high quality and medium scale (that is, 1:25 000 to $1: 100000$ ) data and information at a regional or national level, though in very large countries, it is likely that the availability of data and information is likely to be at much smaller scales. However, OSMG points the way to how a wide range of users of geological knowledge might obtain the information that they need and in the form that they want, quickly, easily and remotely in the near-future.

\section{CONCLUSIONS}

Historically, the key role of geological surveys and equivalent organisations has been the collection, management and interpretation of geological data and its presentation in the form of maps, memoirs and reports. However, the rapid increase in the ease of both collecting and copying spatial data digitally has led to the development of information systems that can provide spatial interpretations of the data for a range of potential users and uses. However, such systems, to be of use, require that the data are comprehensive and, preferably, at a medium scale. For some long-established geological surveys, these requirements have largely been met and so digital, spatial information systems are becoming available.

For the construction and the maintenance of pipelines, which are constructed below or on the ground surface, there is a need for geological information to inform designers and constructors about, for example, the ease of excavation, the depth to the groundwater table, susceptibility to flooding and susceptibility to geohazards that might affect the construction and operation of a pipeline. An information system for identifying risks from landslides and dissolution has been developed for Great Britain's natural gas 
and ethylene pipeline distribution networks. The information system is based on a landslide and dissolution susceptibility interpretation of the national, geological maps at a scale of 1:50 000. This interpretation allowed the pipeline operators to meet their obligations to understand the risk of pipeline rupture from these geohazard events.

Geological information was also needed for the Thames Estuary flood defence system, which consists of almost $250 \mathrm{~km}$ of flood embankments. If projections of sea-level rise are correct, some, at least, of the embankments will need to be heightened. However, the increased loads on soft, compressible alluvial deposits may make the embankments settle. Consequently, there was a need for an assessment of this susceptibility. The information was presented as a series of annotated cross sections. This assessment has led to the development of simplified proforma that can provide non-geological project managers with a first-pass explanation of lengths of linear infrastructure routes that may be more hazardous and hence involve greater costs.

In the future, it is likely that the interpreted information from the original datasets will not be provided prescriptively. Rather, systems will be devised which allow users to dip into the datasets and develop their own information sets that are relevant to the specific questions that they need to answer.

\section{ACKNOWLEDGEMENTS}

This paper is published with the permission of the Executive Director of the British Geological Survey (NERC).

\section{REFERENCES}

Anon. 2007. Absolute Fixing of Tide Gauge Benchmarks and Land Levels: Measuring Changes in Land Level and Sea Level around the coast of Great Britain and along the Thames Estuary using GPS, Absolute Gravimetry, Persistent Scatterer Interferometry and Tide Gauges. R\&D Technical Report FD2319/TR. DEFRA/Environment Agency, London.

Anon. 2009. The Thames Estuary 2100. Environmental Report Summary. Environment Agency, London.

Anon. 2012. Thames Estuary 2100. Managing flood risk through London and the Thames estuary. TE2100 plan. Environment Agency, London.

British Geological Survey. 2010. Digital Geological Map Great Britain 1: 50000. Version 6. (Nottingham: British Geological Survey)

Culshaw, M. G. 1993. Subsidence, geo-hazards and buildings insurance. In: Cripps, J. C. \& Dennis, J. A. (eds), Proceedings of a One Day Multidisciplinary Seminar on "Housing Subsidence," Leeds. Yorkshire Regional Group of the Geological Society. 5-8.

Culshaw, M. G. \& Kelk, B. 1994. A national geo-hazard information system for the UK insurance industry - the development of a commercial product in a geological survey environment. In: Proceedings of the 1st European Congress on Regional Geological Cartography and Information Systems, Bologna, Italy, 4, Paper 111, 3p.

Culshaw, M. G., \& Harrison, M. 2010. Geo-information systems for use by the UK insurance industry for 'subsidence' risk. In: Williams, A.L., Pinches, G.M., Chin, C.Y., McMorran, T.J. \& Massey, C.I. (eds), 'Geologically active.' Proceedings of the $11^{\text {th }}$ Congress of the International Association for Engineering Geology and the Environment, Auckland, New Zealand, September 2010 (on CD-ROM, 10431051). CRC Press/Balkema, Leiden, The Netherlands.

Culshaw, M. G., Jackson, I. \& Giles, J. R. A. 2006. The provision of digital spatial data for engineering geologists. Bulletin of Engineering Geology and the Environment, $65,185-194$. 
Cooper, A. H., Farrant, A. R., Adlam, K. \& Walsby, J. C. 2001. The development of a national Geographic Information System (GIS) for British karst geohazards and risk assessment. In: Beck, B. \& Herring, G. (eds). Geotechnical and environmental applications of karst geology and hydrology. Proceedings of the $8^{\text {th }}$

Multidisciplinary conference on Sinkholes and the Engineering and Environmental Impacts of Karst. Louisville, Kentucky. Balkema. Lisse, 125-130.

Dearden, R. \& Price, S. 2011. A national suitability dataset for infiltration-based sustainable drainage systems. In: Savić, D., Kapelan, Z. \& Butler, D. (Editors), Proceedings of the Eleventh International Conference on Computing and Control for the Water Industry. Centre for Water Systems, University of Exeter, Exeter, UK, 1, 253-258.

Dearden, R. \& Price, S., 2012. A proposed decision-making framework for a national infiltration SuDS map. Management of Environmental Quality: An International Journal, 23(5), 478-485.

Dearden, R. A., Marchant, A. \& Royse, K. 2013. Development of a suitability map for infiltration sustainable drainage systems (SuDS). Environmental Earth Sciences, DOI 10.1007/s12665-013-2301-7

Farrant, A. R. \& Cooper, A.H. 2008. Karst geohazards in the UK: the use of digital data for hazard management. Quarterly Journal of Engineering Geology and Hydrogeology, 41, 339-356.

Foster, C., Pennington, C. V. L., Culshaw, M. G. \& Lawrie, K. 2012. The National Landslide Database of Great Britain: development, evolution and applications. Environmental Earth Sciences, 66, 3, 941-953.

Ford, J. R., Mathers, S. J., Royse, K. R., Aldiss, D. T., \& Morgan, D. J. R. 2010. Geological 3D modelling: scientific discovery and enhanced understanding of the subsurface, with examples from the UK. Zeitschrift der Deutschen Gesellschaft für Geowissenschaften, 161, 205-218.

Gehrels, W. R. 2010. Late Holocene land- and sea-level changes in the British Isles: implications for future sea-level predictions. Quaternary Science Reviews, 29, 1648-1660.

Harrison, M. \& Forster, A. 2009. The assessment of national scale geohazard potential through the application of GIS modelling. In: Culshaw, M.G., Reeves, H.J., Jefferson, I. \& Spink, T.W. (eds), "Engineering Geology of Tomorrow's Cities." Geological Society, London, Engineering Geology Special Publication 22, CD paper number 286.

Rosenbaum, M. S. \& Culshaw, M. G. 2003. Communicating the risks arising from geohazards. Journal of the Royal Statistical Society, Series A, 166, 261-270.

Self, S. J., Entwisle, D. C. \& Northmore, K. J. 2012. The structure and operation of the BGS National Geotechnical Properties Database Version 2. British Geological Survey Internal Report, IR/12/056. British Geological Survey, Keyworth, Nottingham, 61p.

Walsby, J.C. 2007. Geohazard information to meet the needs of the British public and governmental policy. Quaternary International, 171/172, 179-185.

Walsby, J.C. 2008. GeoSure; a bridge between geology and decision-makers. In: Liverman, D.G.E., Pereira, C.P.G. \& Marker, B. (eds.) Communicating environmental geoscience. Geological Society, London, Special Publications, 305, 81-87.

Waltham, A. C., Bell, F. G. \& Culshaw, M. G. 2005. Sinkholes and subsidence: karst and cavernous rocks in engineering construction. Springer, Berlin and Praxis Publishing, Chichester, 382p. 